\title{
Estimation of the quality factor based on the microseismicity recordings from Northern Poland
}

\author{
Paweł Wandycz $^{1}$ - Eryk Święch ${ }^{1} \cdot$ Leo Eisner $^{2} \cdot$ Andrzej Pasternacki $^{1,3} \cdot$ Miłosz Wcisło $^{4} \cdot$ Tomasz Maćkowski $^{1}$
}

Received: 3 June 2019 / Accepted: 11 September 2019 / Published online: 21 September 2019

(c) The Author(s) 2019

\begin{abstract}
We use the peak frequency method to estimate effective P- and S-wave quality factors $\left(Q_{\mathrm{P}}\right.$ and $\left.Q_{\mathrm{S}}\right)$ based on the recorded waveforms of microseismic events. We analyze downhole datasets recorded during the hydraulic stimulation of the two unconventional gas reservoirs located in the northern part of Poland. The effective attenuation is lower in the deeper reservoir consistent with higher compaction. In both cases, we observe high $Q_{\mathrm{S}}$ values relative to $Q_{\mathrm{P}}$ which is consistent with attenuation coefficients of saturated reservoirs.
\end{abstract}

Keywords Attenuation · Microseismicity · Polish shale gas · Quality factor

\section{Introduction}

Microseismic monitoring is usually used to map source locations and mechanisms of microseismic events induced by hydraulic fracture or stress changes in the reservoir, in which there is a gas production (Maxwell et al. 2010; Duncan and Eisner 2010). However, the microseismicity also provides information on the medium properties as the seismic waves travel through the reservoir (Grechka et al. 2012). This information can be used to assess the reservoir, improve microseismic imaging or to design optimal microseismic monitoring.

One of the fundamental properties of the reservoir that can be recovered from seismic wave propagation is seismic attenuation quantified by quality factor $(Q)$. Attenuation can

Paweł Wandycz

pwandycz@agh.edu.pl

1 Department of Fossil Fuels, Faculty of Geology, Geophysics and Environment Protection, AGH University of Science and Technology in Krakow, Al. A. Mickiewicza 30, 30-059 Kraków, Poland

2 Seismik s.r.o., Kubišova 1265/8, 18200 Prague 8, Czech Republic

3 Shell Business Operations Krakow, Data - Upstream Projects and Technology Kraków, ul. Czerwone Maki 85, 30-392 Kraków, Poland

4 Institute of Rock Structure and Mechanics, The Czech Academy of Sciences, V Holešovičkách 94/41, 18209 Prague 8, Czech Republic be described as the frictional energy loss per cycle (Aki and Richards 2002), and it is routinely measured in VSP experiments (e.g., Rutledge and Winkler 1989) or estimated from sonic logs (e.g., Liner 2014). Drwiła et al. (2019) showed that incorporating attenuation measurements is also an important factor in the calculation of the moment magnitudes of the recorded events. In addition, the quality factor obtained from microseismicity can be also of use in the performance evaluation of the monitoring networks (Wandycz et al. 2018).

Eisner et al. (2013) proposed derived theory to predict the peak frequency of observed microseismic event waveforms and showed it is consistent with surface and downhole monitoring datasets. Wcisło and Eisner (2016) developed the peak frequency methodology further and developed a new methodology to obtain more accurate results both on downhole monitoring dataset and for the surface monitoring (Wcisło et al. 2017).

In this study, we measure effective attenuation in two unconventional gas reservoirs located in the northern part of Poland in the vicinity of the Lubocino and Wysin villages. Both experiments were recorded with downhole monitoring arrays.

\section{Geological settings}

The research area is located in the western part of a Lower Paleozoic basin known as a Baltic Basin, which is located in the northernmost part of the Polish segment of the 
Baltica continent, also referred to as an East European Craton (EEC). The Baltic Basin is filled by the sedimentary sequence ranging in age from the Cambrian to the Silurian. The Cambrian is represented mainly by terrigenous sediments deposited during the opening of the Tornquist Ocean (e.g., Golonka 2007). Due to the latest Cambrian erosional event, the lack of the Upper Cambrian sediments is a widely observed phenomenon. During the Ordovician times, present-day western edge of the EEC acted as a passive margin. Because of low subsidence rates, the Ordovician period is represented by a thin sequence, rarely exceeding $100 \mathrm{~m}$, predominantly composed of mudstones and carbonates. The docking of the Avalonia microcontinent along the western edge of the EEC at the end of the Ordovician resulted in formation of a foredeep in front of the Caledonian orogeny and significant increase in subsidence rates (e.g., Poprawa et al. 1999; Poprawa 2006a, b). The foredeep was filled up with a thick sequence (up to $2000 \mathrm{~m}$ ) of Silurian fine-grained terrigenous sediments. According to published paleofacies maps (Modliński et al. 2010), sedimentations continued during the Devonian and Carboniferous times. However, due to the Carboniferous erosional episode linked with the Variscan orogeny (e.g., Matyja 2016), these rocks are only partially preserved in the narrow zone along the western edge of the EEC. Except that zone, within the Baltic Basin, the Silurian rocks are covered by the flat-lying permo-mesozoic sequence starting from Lower Permian terrigenous sequence (the Rotliegend) and followed by the Upper Permian evaporates (Zechstein). The Mesozoic era is represented by mixed terrigenous and carbonate rocks deposited during cyclic transgressions and regressions of epicontinental seas (Dadlez et al. 1995, 1998).

\section{Dataset description}

The datasets used for this study were obtained during experiments of the hydraulic fracturing jobs in Northern Poland (Fig. 1). Stimulation of two separate gas bearing formations was performed in two horizontal wells, Lubocino $2 \mathrm{H}$ and $\mathrm{Wysin} 2 \mathrm{H} / 2 \mathrm{Hbis}$.

The first stimulation experiment took place in January 2013 and was aimed to stimulate approximately 30-m-thick layer of Lower Silurian and Ordovician strata at the depth of around $2800 \mathrm{~m}$ in the Baltic Basin Margin. For this purpose, two wells were drilled in Lubocino village: Lubocino 1 and Lubocino $2 \mathrm{H}$. The first exploration well Lubocino 1 was drilled vertically through the shale formation. The stimulation process took place in the approximately 700-m-long horizontal section of the Lubocino $2 \mathrm{H}$ well. The stimulation experiment was divided into six stages starting at the toe of the horizontal section and progressing to its heel. Connection with the formation was achieved using sand jetting in the first stage and a total number of 11 perforation shots in stages 2-6. Downhole microseismic monitoring consisted of $113 \mathrm{C}$ geophones deployed in the monitoring well Lubocino 1 . The whole array was spanning approximately true vertical depth from $2515 \mathrm{~m}$ to $2665 \mathrm{~m}$ below the surface level. Due to the borehole conditions, it was not possible to place receivers at stimulation depth (Fig. 2).

The second dataset was acquired during the hydraulic fracturing job in the well Wysin 2H/2Hbis in July 2017. The stimulation process was recorded by the downhole monitoring array which was deployed in a vertical exploration well, Wysin 1 . The downhole network consisted of 18 $3 \mathrm{C}$ geophones, with the lowest receiver placed at the depth of $3700 \mathrm{~m}$ below the surface. Spacing between the six uppermost receivers was set to $30 \mathrm{~m}$, and between receivers from 6 to 18 , the spacing was set to $15 \mathrm{~m}$, giving a total length of the array of $330 \mathrm{~m}$, almost two times longer than in the case of the Lubocino array. Unfortunately, it was not possible to place the array so that it would span across the stimulated interval. The lowest receiver was placed approximately at the stimulated interval.

Connection to the formation was performed in 11 stages of the hydraulic fracturing in the horizontal section of the Wysin 2H/2Hbis well. The whole operation of fracturing was located at a distance ranging from $1600 \mathrm{~m}$ (first stage) to $500 \mathrm{~m}$ (last stage) from the monitoring array deployed in Wysin 1 well. In each stage of the fracturing, six perforation shots were performed giving a total number of 66 perforation shots for the whole operation (Fig. 2).

The locations of the microseismic events recorded during the stimulation of the Lubocino $2 \mathrm{H}$ were obtained using a 1D-anisotropic-layered velocity model constructed from the sonic $\log$ f for $\mathrm{P}$ and $\mathrm{S}$ waves available for the Lubocino 1 well. During the six stages of the fracturing in Lubocino $2 \mathrm{H}$ well, 11 perforation shots and 844 microseismic events were located. Moment magnitudes of the located events ranged between $\mathrm{Mw}-3.5$ and $\mathrm{Mw}-1.5$. The vast majority of the located microseismic events come from the stages from 4 to 6 . Only around $13 \%$ of the total number of events come from the most distant stages 1-3.

This dataset was the subject of several publications (Gajek et al. 2016; Święch et al. 2017; Gajek et al. 2018; Wandycz et al. 2018), where more detailed information about the processing procedure and interpretation of microseismicity can be found. 


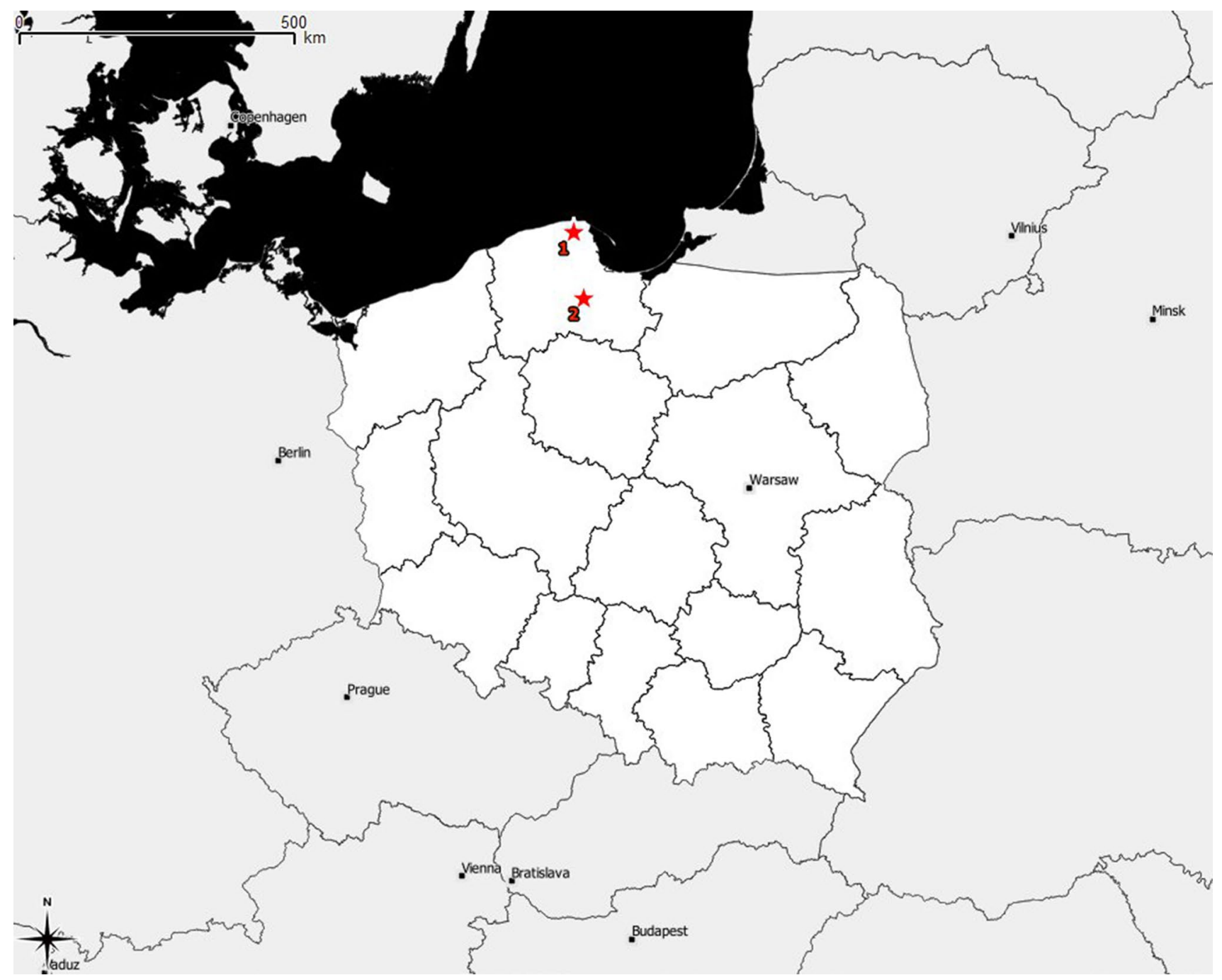

Fig. 1 Location of the Lubocino (1) and Wysin (2) well pads (red stars)
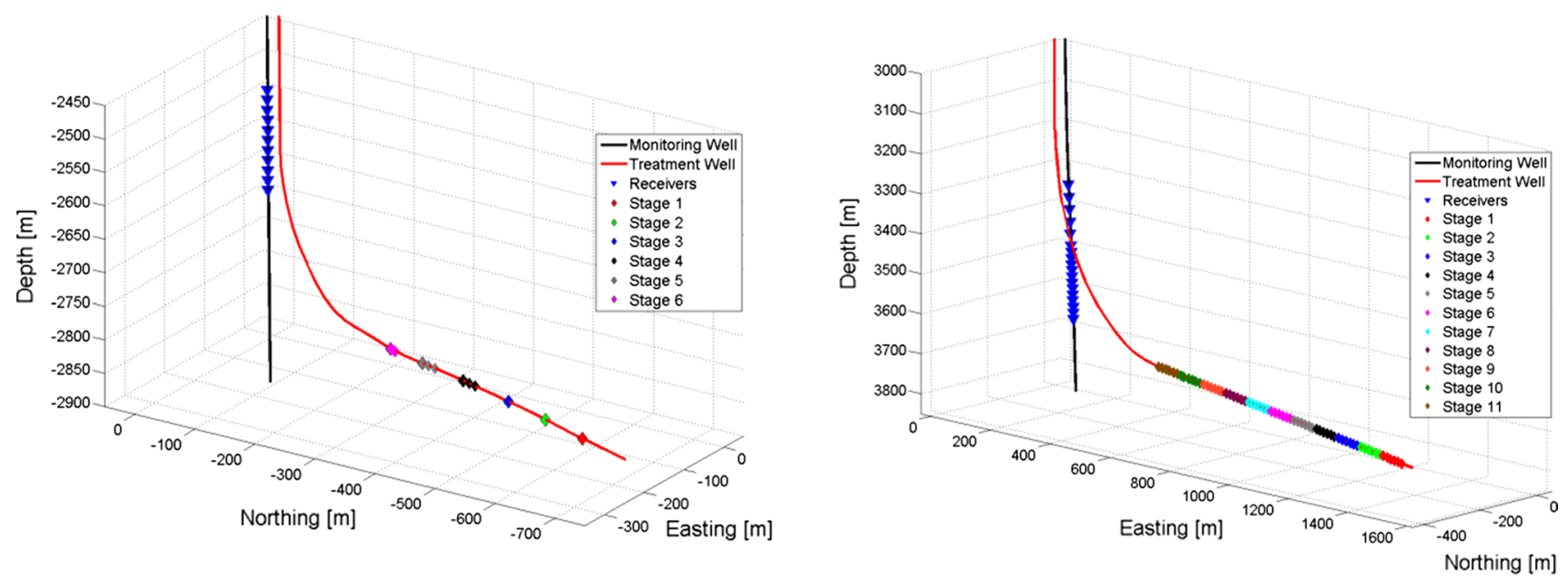

Fig. 2 Array geometry along with treatment and monitoring wells. Left side of the picture is Lubocino, right side Wysin. Triangles indicate receivers, and diamonds indicate perforation shots. Stages are color coded 


\section{Wysin $2 \mathrm{H} / 2 \mathrm{Hbis}$ experiment}

For the detection of the microseismic events, we used a simple STA/LTA (Withers et al. 1998) algorithm that allowed us to detect several hundreds of microseismic events. For the location of the microseismic events, we used a 1D-isotropiclayered velocity model constructed on a base of sonic log both for $\mathrm{P}$ and $\mathrm{S}$ waves from the Wysin 1 well (Fig. 3).

As we were not able to properly locate perforation shots using a single velocity model, we calibrated the initial velocity model separately for each stage, based on the perforation shots from the corresponding stage. Recorded signals of the perforation shots were dominated by the P-wave energy, as for most of the cases we were not able to properly pick $S$ waves on most of the receivers.

In stages 1 and 2, we were able to locate only 6 and 12 events, respectively, but for the next stages, the number of located events increased to approximately 50 and the highest number of the located events was in stage 10 , where we

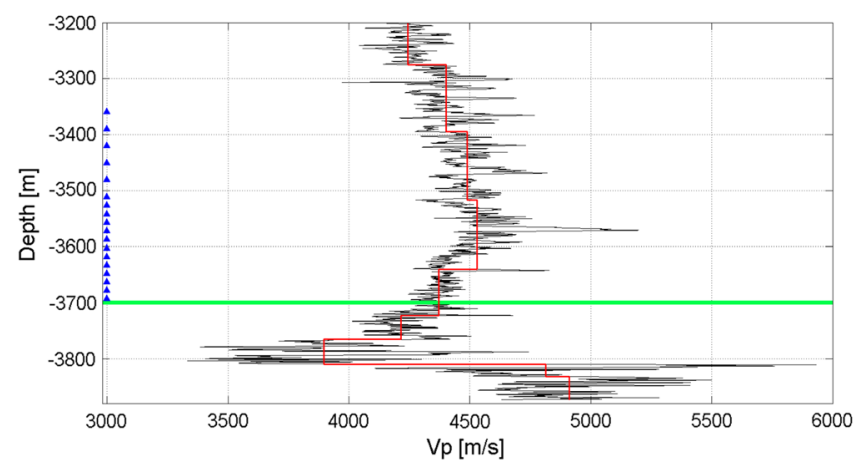

located 92 microseismic events, giving the total number of 562 events from all 11 stages of the stimulation (Fig. 4).

\section{Method and theory}

Eisner et al. (2013) showed that effective attenuation quantified by quality factors $Q_{\mathrm{P}}$ and $Q_{\mathrm{S}}$ for $\mathrm{P}$ and $\mathrm{S}$ waves, respectively, can be estimated from the peak frequency of observed microseismic events measured at downhole or surface receivers. These factors can be estimated from a simple equation:

$Q=\pi f_{\text {peak }} \Delta t$,

where $f_{\text {peak }}$ is the peak frequency of the corresponding seismic wave and the $\Delta t$ is travel time of the corresponding seismic wave from the microseismic event to the receiver. This equation is generally valid in a heterogeneous medium and provides attenuation factor corresponding to the homogeneous attenuation between the source and the receiver

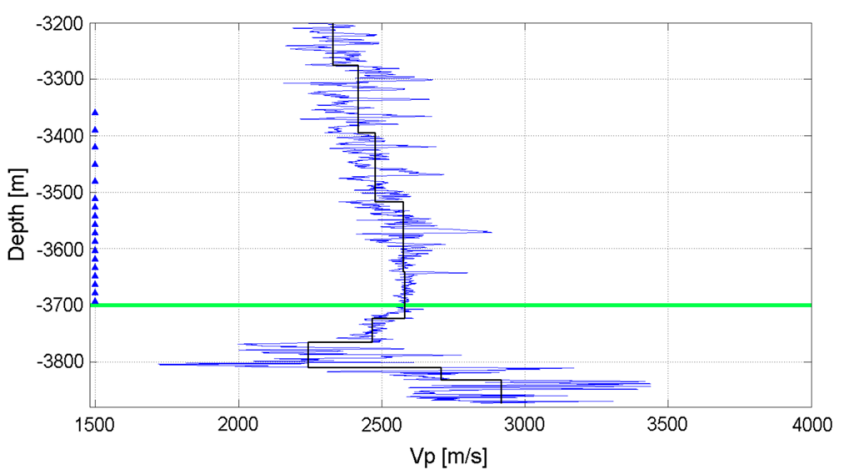

Fig. 3 Compressional and shear sonic logs (black and blue, respectively) and layered velocity models (red and black, respectively) of the Wysin area. The blue triangles represent the depth of the monitoring receivers; the green line is approximately at depth of the stimulated well

Fig. 4 Map view of the located microseismic events from Wysin dataset. Events are color coded by stage

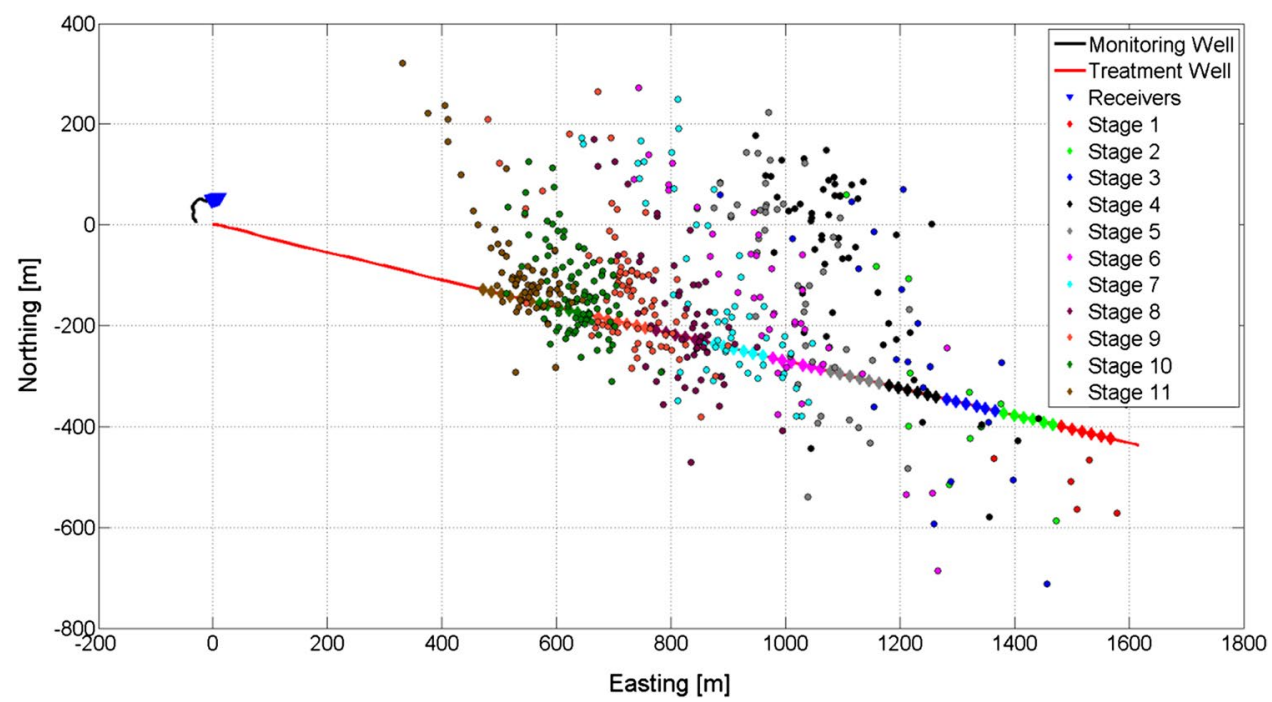


(Eisner et al. 2013). Determining accurate measurements of attenuation factor $Q$ by using the peak frequency method relies on two parameters: the travel time $\Delta t$ which is dependent on the assumed velocity model and the peak frequency measured at the receivers. Figure 5 shows an example ray path used for the calculation of the travel times of $\mathrm{P}$ and $\mathrm{S}$ waves in this study.

To measure the peak frequency $\left(f_{\text {peak }}\right)$, we can use either fast Fourier transform (FFT) or half-period measurement. Wcisło and Eisner (2016) showed in their work that the second approach gives a more reliable and consistent measurement of the peak frequency. An example of $f_{\text {peak }}$ measurement is illustrated in Fig. 6.

The peak frequency for the $\mathrm{P}$ wave was measured on the north component for all of the receivers, as in both cases this component is nearly parallel to a radial direction. For the determination of $f_{\text {peak }}$ for the $S$ wave, we used horizontal components to consistently measure SH wave. Quality factor for each event was calculated as a mean value of this parameter estimated on individual receivers.

\section{Results}

From the Lubocino dataset, we selected 33 representative events with a good signal-to-noise ratio for the measurements of attenuation. Selected events came from stages 1 , 2, 4 and 5. We were not able to select events from stages 3 and 6 both for $\mathrm{P}$ and $\mathrm{S}$ waves and from stage 2 for $\mathrm{P}$ wave as waveforms, for those stages were contaminated by the superposition of several waves and obtained $f_{\text {peak }}$ values were therefore not reliable. Figure 7 shows an example of the P-wave arrival of an event from stage 2 interfered by the guided waves.

Event locations ranged from around $300 \mathrm{~m}$ distance from the nearest receiver for stage 5-650 $\mathrm{m}$ for stage 1 . The mean value of the quality factors slightly increased with the distance between events and monitoring array (Fig. 8). The P-wave attenuation factor was lowest in stage 5 with 64 mean value and was slightly higher at 70 and 74 in stages 4 and 1.

Figure 9 shows the calculated value of $Q_{\mathrm{P}}$ for five chosen events. Each dot represents the value of $Q_{\mathrm{P}}$ for a specific receiver. The scatter of $Q_{\mathrm{P}}$ is independent of the receiver.

In the case of the $\mathrm{S}$ wave, we were able to determine the peak frequency on events from all of the previously selected stages as the signal is generally higher. Figure 8 shows that the highest values of S-wave attenuation factors are observed in stage 2 with the mean of 90 . In stages 1 , 4 and 5 , the means of quality factor for $\mathrm{S}$ wave are similar and equal to 84, 72 and 74, respectively. In the case of the attenuation factor for the $\mathrm{P}$ wave, results from stage 2 are the least reliable because of the guided waves that partly interfere with the direct $\mathrm{S}$-wave arrival. We conclude that the results from stages 1,4 and 5 are reliable and we do not see any significant trend with the distance.

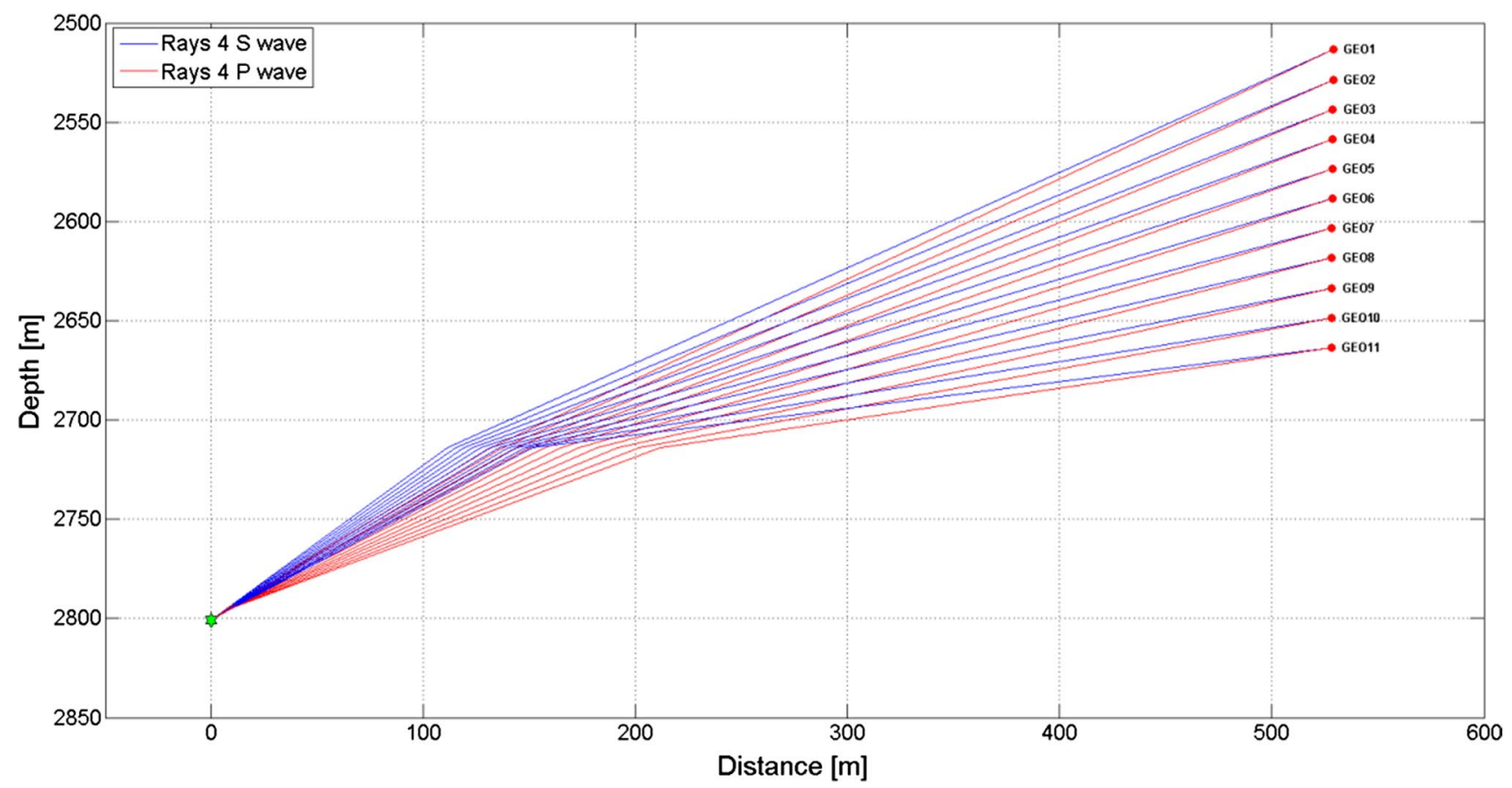

Fig. 5 1D ray tracing from the true location of the event to each receiver ( $\mathrm{P}$ waves are represented by red lines and $\mathrm{S}$ waves by blue lines). Green star is the location of the event, and red dots indicate receivers 


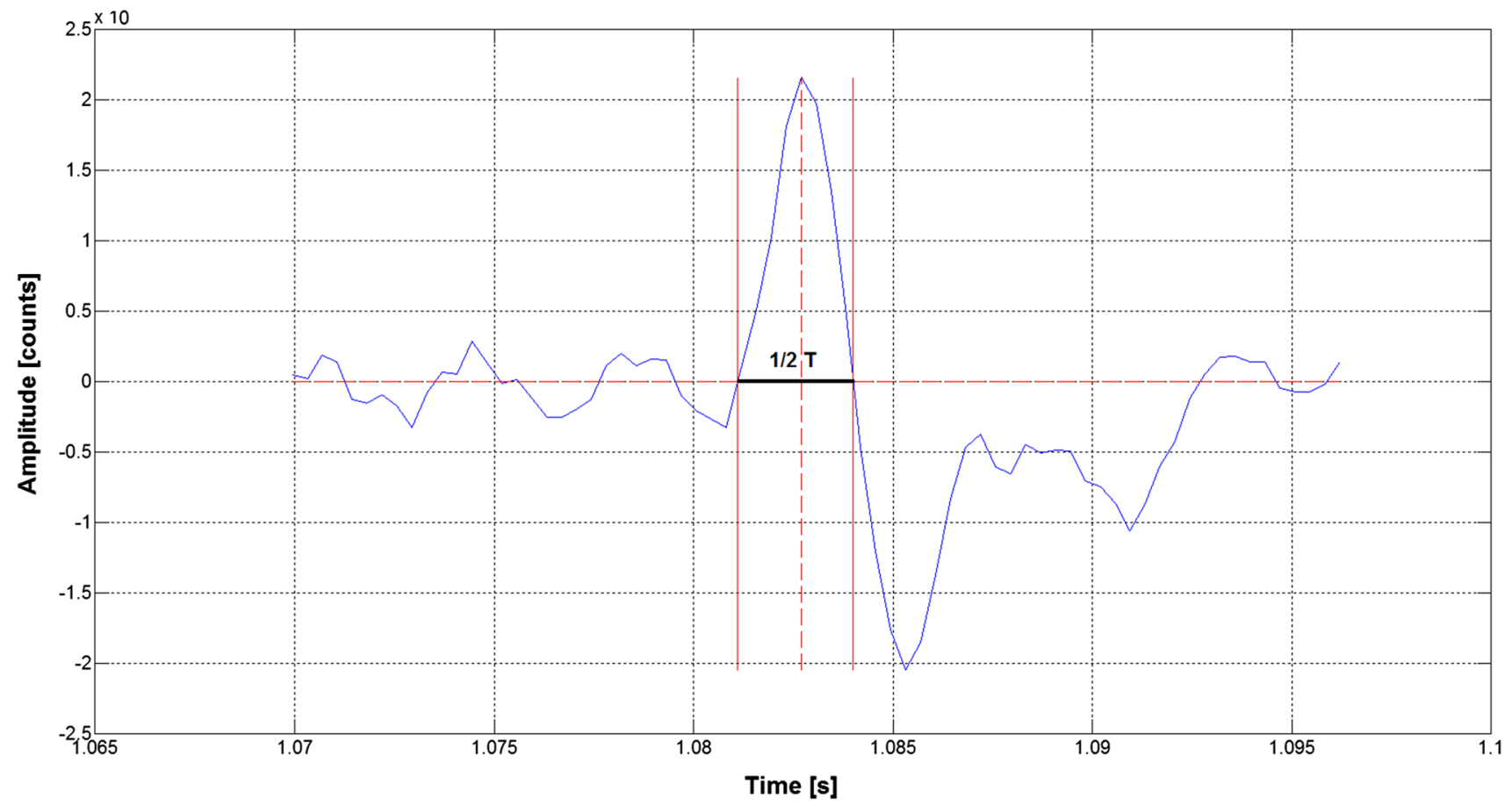

Fig. 6 Particle velocity recording on the downhole instrument (horizontal component) as of the strong microseismic event. The peak frequency of the $\mathrm{S}$ wave is measured as the time interval between two zero crossings marked by the vertical red lines

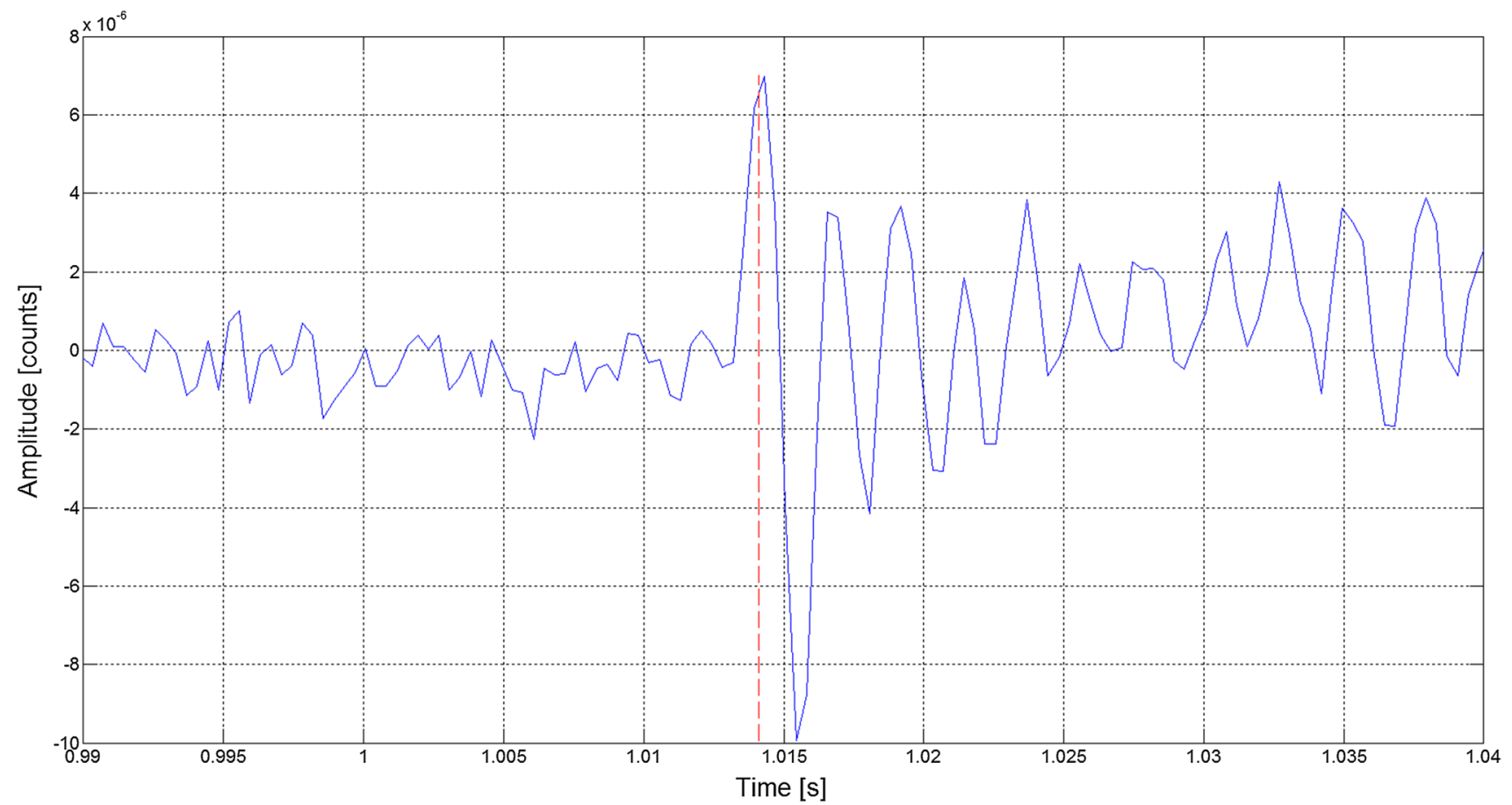

Fig. 7 Example of particle velocity recording on a downhole instrument (vertical component) for the event from stage 2 recorded during Lubocino experiment. P-arrival (dashed vertical red line) is followed by the guided waves 


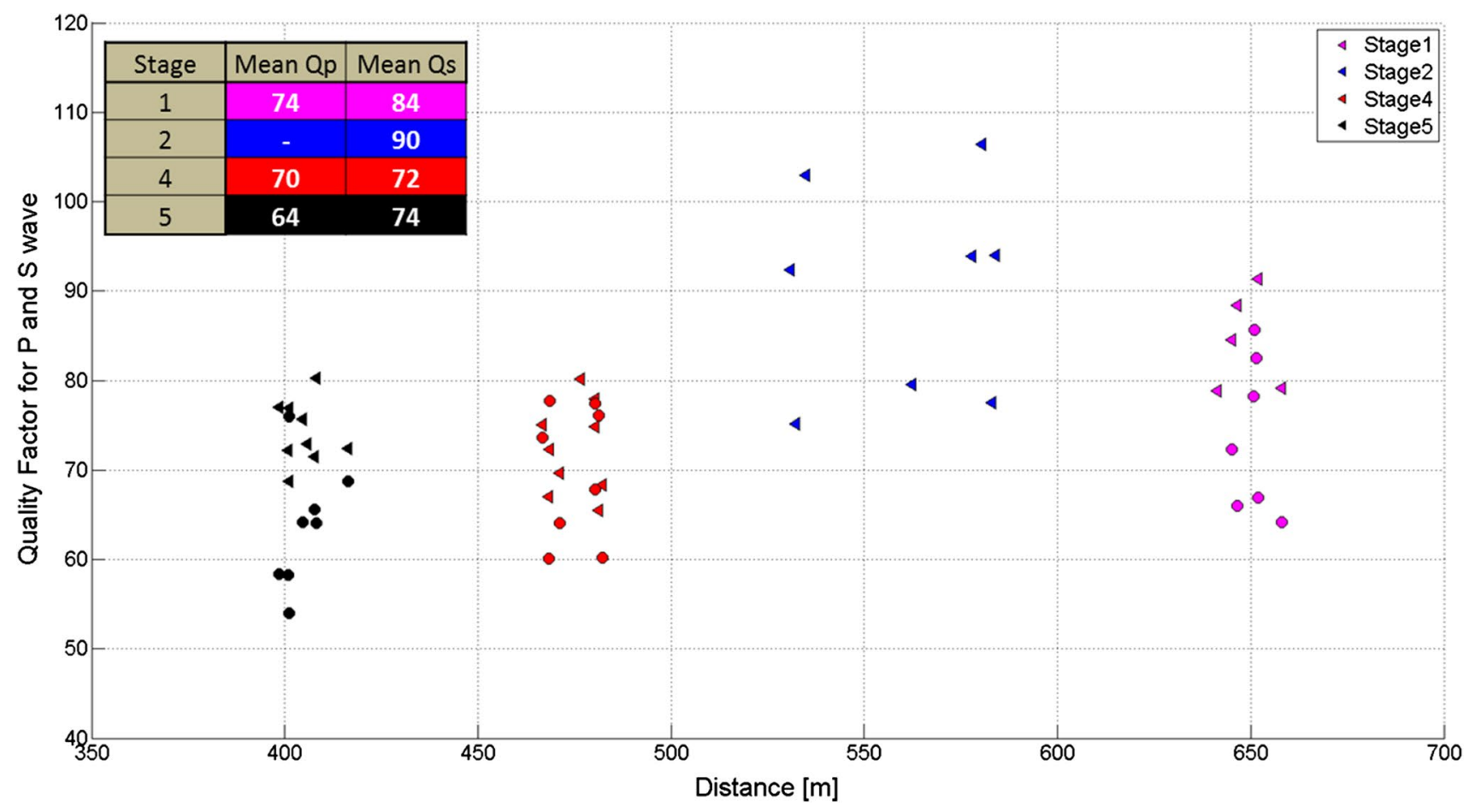

Fig. 8 Calculated quality factor for $\mathrm{P}$ wave (circle) and $\mathrm{S}$ wave (triangles) from stages 1, 2, 4 and 5 (color coded)

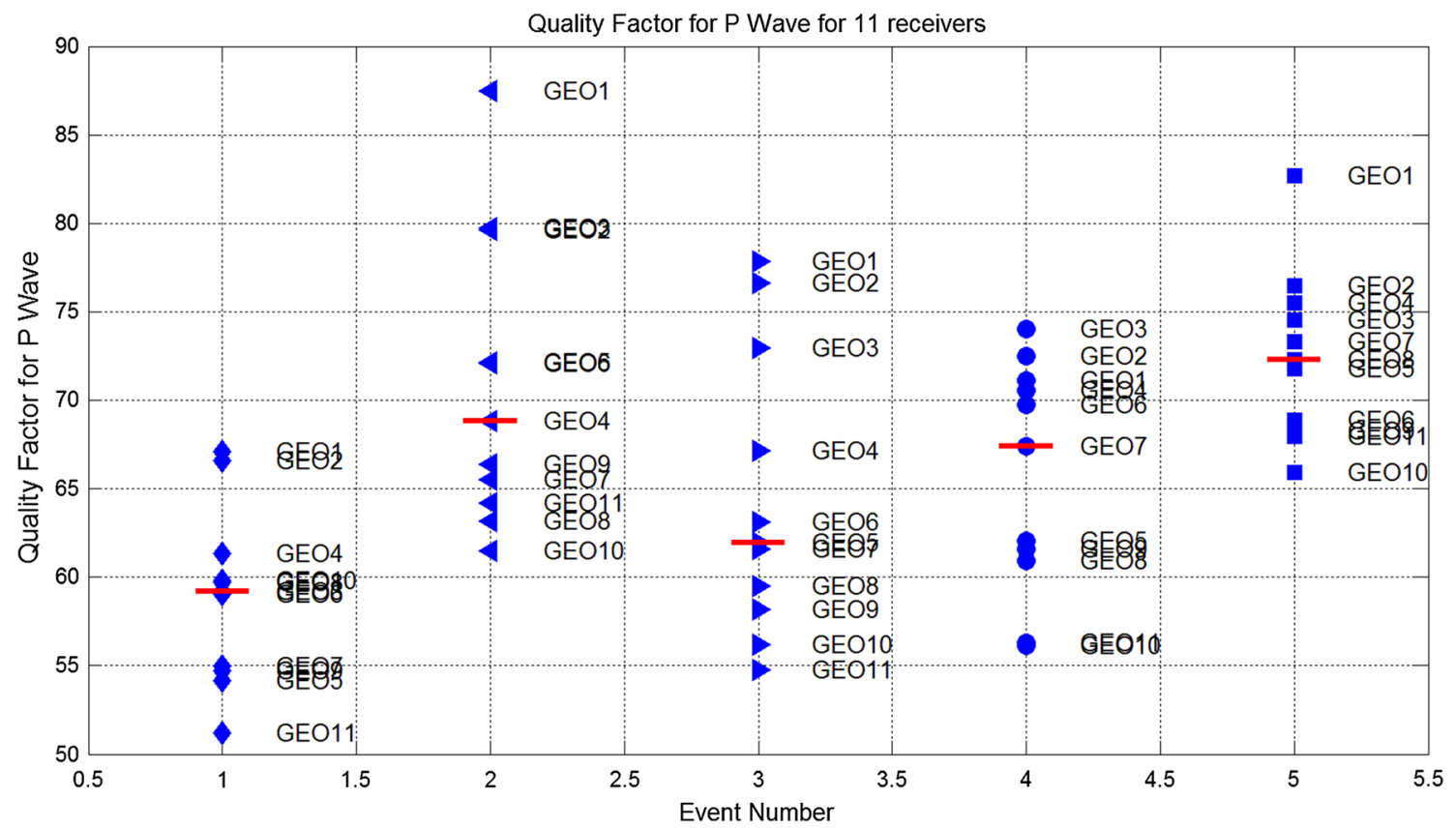

Fig. 9 Example of calculation of the quality factor for $\mathrm{P}$ wave, for five events. Different symbols correspond to specific events. Each mark represents $Q$ value calculated on specific receiver

For the measurements of attenuation in the Wysin $2 \mathrm{H} / 2 \mathrm{Hbis}$ well, we were able to calculate a quality factor for 99 events for $\mathrm{P}$ wave and 94 events for the $\mathrm{S}$ wave. We selected two partially overlapping subsets of events for the measurements of attenuation, as in some of the cases we were able to accurately determine the peak frequency only for the $\mathrm{P}$ wave or only for the $\mathrm{S}$ wave. Distance from selected events to the monitoring network ranged from $500 \mathrm{~m}$ for 
events from stage 11 to $\sim 1600 \mathrm{~m}$ for the most distant event recorded during stage 1 . Attenuation measurements for these events are shown in Fig. 10 and summarized in Table 1. We observe that the P-wave quality factor is consistent from stage to stage ranging between 90 and 110 with average value across all stages of approximately 100 . S-wave quality factor measurements are scattered in most distant stages and become more consistent in stages 9-11. $Q_{\mathrm{S}}$ values range from 112 to 135 with an average value of approximately 120 across all stages.

In Fig. 11, we plotted measured peak frequencies and computed travel times for $\mathrm{P}$ and $\mathrm{S}$ waves for both datasets. We observe that in both cases, decay of the peak frequencies follows one line, indicating that the attenuation in both hydraulic fractured parts of reservoirs is homogeneous and isotropic.

\section{Discussion and conclusions}

Using the peak frequency technique, we calculated quality factor for $\mathrm{P}$ and $\mathrm{S}$ waves on two downhole datasets of lower Silurian and Ordovician strata from Northern Poland. We measure effective quality factors in the fractured interval. The observed $\mathrm{P}$-wave and S-wave effective attenuation factors range from 60 to 90 for the Lubocino dataset. Within this dataset, observed increased values of $Q_{\mathrm{S}}$ in stage 2 are most likely caused by the presence of the guided waves interfering with the direct S-wave arrival. In the case of the Wysin, the observed effective values of attenuation factors are higher with P- and S-wave average values of 100 and 124 , respectively. We show that the observed peak frequency across both fractured reservoirs is consistent with being homogenous and isotropic. Estimated P- and S-wave quality factors in both studied datasets are in general agreement with the results obtained by other authors (Wcisło and Eisner 2016; Jyothi et al. 2017; Drwiła et al. 2019). In both cases,
Fig. 10 Calculated quality factor for $\mathrm{P}$ wave (circle) and $\mathrm{S}$ wave (triangles) from all stages of fracturing of Wysin2 $\mathrm{H} / 2 \mathrm{Hbis}$ well. Events are color coded by stage
Table 1 Quality factor estimates for $\mathrm{P}$ and $\mathrm{S}$ waves in stages for Wysin dataset

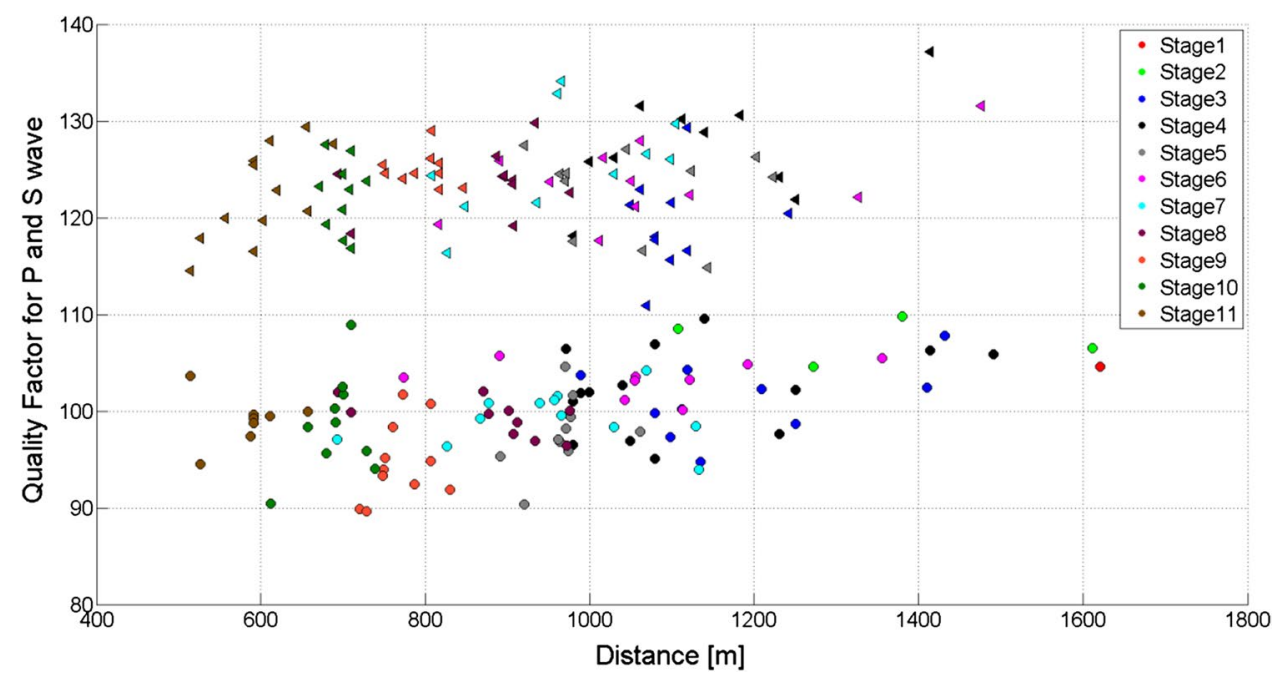

\begin{tabular}{|c|c|c|c|c|c|c|c|c|}
\hline & \multicolumn{4}{|l|}{$Q_{\mathrm{P}}$} & \multicolumn{4}{|l|}{$Q_{\mathrm{S}}$} \\
\hline & $N$ & Mean & Min & Max & $N$ & Mean & Min & Max \\
\hline Stage 1 & 1 & 105 & 105 & 105 & - & - & - & - \\
\hline Stage 2 & 4 & 107 & 105 & 110 & - & - & - & - \\
\hline Stage 3 & 10 & 101 & 95 & 108 & 10 & 119 & 111 & 129 \\
\hline Stage 4 & 14 & 102 & 95 & 110 & 10 & 127 & 118 & 137 \\
\hline Stage 5 & 10 & 98 & 90 & 105 & 11 & 123 & 115 & 127 \\
\hline Stage 6 & 9 & 103 & 100 & 106 & 11 & 124 & 118 & 132 \\
\hline Stage 7 & 12 & 99 & 94 & 104 & 10 & 126 & 116 & 134 \\
\hline Stage 8 & 10 & 99 & 96 & 102 & 10 & 124 & 118 & 130 \\
\hline Stage 9 & 11 & 95 & 90 & 102 & 10 & 125 & 123 & 129 \\
\hline Stage 10 & 10 & 99 & 90 & 109 & 10 & 122 & 117 & 128 \\
\hline Stage 11 & 8 & 99 & 95 & 104 & 12 & 122 & 115 & 129 \\
\hline
\end{tabular}


Fig. 11 Peak frequency as a function of travel time for Lubocino $2 \mathrm{H}$ (triangles). Solid lines represent analytically calculated peak frequencies with constant $Q=70$ (black), $Q=50$ (green) and $Q=125$ (magenta) Wysin $2 \mathrm{H} / 2 \mathrm{Hbis}$ (circle) and

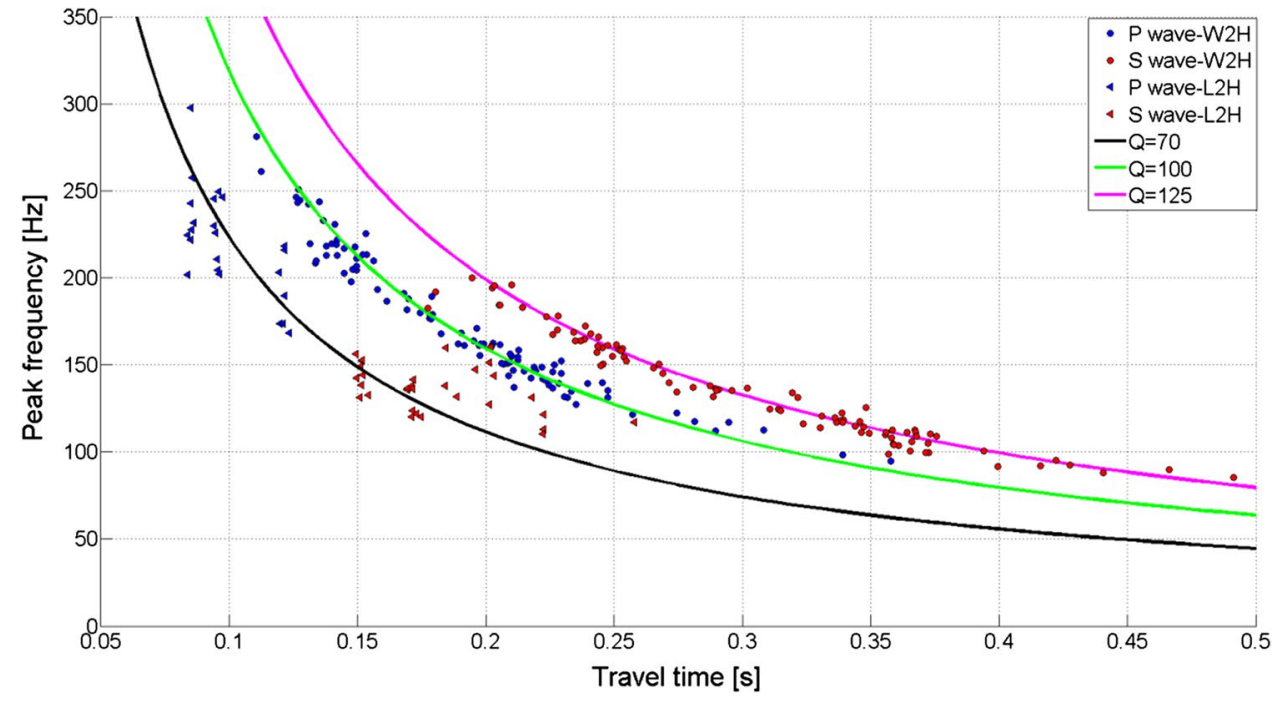

\section{Compliance with ethical standards}

we observe elevated values of $Q$ for the $\mathrm{S}$ wave relative to saturated sedimentary reservoirs (Pham et al. 2002). As the lithological composition of the stimulated intervals in both experiments is broadly similar, lower attenuation obtained in Wysin dataset is most likely related to the increased pressure and compaction at lower depths (Carcione 2000).

The low attenuation was one of the key factors that increased the detection range for both monitoring networks in this basin. In the case of Lubocino where attenuation was slightly higher, we were able to detect and locate only a handful of events in the distance higher than $500 \mathrm{~m}$. However, in Wysin monitoring where the attenuation is lower, we located almost 100 events at similar distance. This observation should be taken into consideration at the stage of design of the monitoring networks, especially in cases where the downhole array is located at significant distances from the stimulation area.

Acknowledgements This study is part of the project "Appraisal of microseismic monitoring techniques of hydraulic fracturing and development of optimal processing and interpretation methodologies" (SHALEGASMICROS), funded by the Polish National Center for Research and Development within the Program Blue Gas. The authors are grateful to PGNiG S.A. for generously providing downhole data for research purposes. This study was also partially funded by AGH-UST statutory grant no 15.11.140.870, 15.11.140.872 and 11.11.140.176. This work was also supported within the frame of the long-term conceptual development of research organization RVO: 67985891 and by Charles University grant SVV 260447. We also thank Dr. Jan Barmuta for his input on geology section, Dr. Michele Pierotti for his valuable comments and language correction and Dr. Marta Waliczek for her help with preparation of this article. The paper was presented at the CAGG 2019 Conference "Challenges in Applied Geology and Geophysics" organized at the AGH University of Science and Technology, Krakow, Poland, 10-13 September 2019.
Conflict of interest On behalf of all authors, the corresponding author states that there is no conflict of interest.

Open Access This article is distributed under the terms of the Creative Commons Attribution 4.0 International License (http://creativeco mmons.org/licenses/by/4.0/), which permits unrestricted use, distribution, and reproduction in any medium, provided you give appropriate credit to the original author(s) and the source, provide a link to the Creative Commons license, and indicate if changes were made.

\section{References}

Aki K, Richards PG (2002) Quantitative seismology, 2nd edn. University Science Books, Sausalito

Carcione JM (2000) A model for seismic velocity and attenuation in petroleum source rocks. Geophysics 65:1080-1092

Dadlez R, Narkiewicz M, Stephenson RA, Visser MTM, van Wees JD (1995) Tectonic evolution of the mid-polish trough: modelling implications and significance for central European geology. Tectonophysics 252:179-195

Dadlez R, Marek S, Pokorski J (eds) (1998) Atlas paleogeograficzny epikontynentalnego permu i mezozoiku w Polsce 1: 2500000. Państwowy Instytut Geologiczny, Warszawa

Drwiła M, Wcisło M, Anikiev D, Eisner L, Keller R (2019) Passive seismic measurement of seismic attenuation in Delaware Basin. Lead Edge 38:138-143

Duncan PM, Eisner L (2010) Reservoir characterization using surface microseismic monitoring: Geophysics 75:75A139-75A146

Eisner L, Gei D, Hallo M, Opršal I, Ali MY (2013) The peak frequency of direct waves for microseismic events. Geophysics 78:A45-A49

Gajek W, Trojanowski J, Malinowski M (2016) Advantages of probabilistic approach to microseismic events location-a case study from Northern Poland. In: 78th EAGE conference and exhibition 2016

Gajek W, Trojanowski J, Malinowski M, Jarosiński M, Riedel M (2018) Results of the downhole microseismic monitoring at a pilot hydraulic fracturing site in Poland-part 1: event location and stimulation performance. Interpretation 6:SH39-SH48 
Golonka J (2007) Phanerozoic paleoenvironment and paleolithofacies maps. Early Paleozoic. Geologia 35(4):589-654

Grechka V, Singh P, Das I (2012) Estimation of effective anisotropy simultaneously with locations of microseismic events. Geophysics 76:WC143-WC155

Jyothi V, Sain K, Pandey V, Bhaumik AK (2017) Seismic attenuation for characterization of gas hydrate reservoir in Krishna-Godavari basin, eastern Indian margin. J Geol Soc India 90:261-266

Liner CL (2014) Long-wave elastic attenuation produced by horizontal layering. Lead Edge 33:634-638

Matyja H (2016) Stratygrafia i rozwój facjalny osadów dewonu i karbonu w basenie pomorskim i w zachodniej części basenu bałtyckiego a paleogeografia pół nocnej części TESZ w późnym paleozoiku Prace Państwowego Instytutu Geologicznego

Maxwell SC, Rutledge J, Jones R, Fehler M (2010) Petroleum reservoir characterization using downhole microseismic monitoring. Geophysics 75:75A129-75A137

Modliński Z, Małecka J, Szewczyk A (2010) Atlas paleogeologiczny podpermskiego paleozoiku kratonu wschodnioeuropejskiego $\mathrm{w}$ Polsce i na obszarach sąsiednich: 1:2000000 $=$ Paleogeological atlas of the sub-Permian Paleozoic of the East-European Craton in Poland and neighbouring areas: 1:2 000 000. Warszawa, Państwowy Instytut Geologiczny

Pham NH, Carcione JM, Helle HB, Ursin B (2002) Wave velocities and attenuation of shaley sandstones as a function of pore pressure and partial saturation. Geophys Prospect 50:615-627

Poprawa P (2006a) Neoproterozoiczno-paleozoicze procesy tektoniczne wzdłuż zachodnigo skłonu Bałtyki-zapis rozpadu i akrecji. In: Matyja H, Poprawa P (eds) Ewolucja facjalna, tektoniczna i termiczna pomorskiego segmentu szwu transeuropejskiego oraz obszarów przyległych, vol 186. Prace Państwowego Instytutu Geologicznego, Warszawa, pp 165-188

Poprawa P (2006b) Rozwój kaledońskiej strefy kolizji wzdłuż zachodniej krawędzi Baltiki oraz jej relacji do basenu przedpola.
In: Matyja H, Poprawa P (eds) Ewolucja facjalna, tektoniczna i termiczna pomorskiego segmentu szwu transeuropejskiego oraz obszarów przyległych, vol 186. Prace Państwowego Instytutu Geologicznego, Warszawa, pp 189-214

Poprawa P, Šliaupa S, Stephenson R, Lazauskiene J (1999) Late Vendian-Early Palaeozoic tectonic evolution of the Baltic Basin: regional tectonic implications from subsidence analysis. Tectonophysics 314:219-239

Rutledge JT, Winkler H (1989) Attenuation measurements from vertical seismic profile data: leg 104, site 642. In: Proceedings of the ocean drilling program, 104 Scientific Results

Święch E, Wandycz P, Eisner L, Pasternacki A, Maćkowski T (2017) Downhole microseismic monitoring of shale deposits: Case study from northern Poland: Acta Geodynamica et Geomaterialia 14:297-304

Wandycz P, Eryk Ś, Eisner L, Pasternacki A, Anikiev D (2018) Special section: Characterization of potential Lower Paleozoic shale resource play in Poland Estimating microseismic detectability of the surface-monitoring network using downhole-monitoring array $6: 1-9$

Wcisło M, Eisner L (2016) Attenuation from microseismic datasets by the peak frequency method benchmarked with the spectral ratio method. Stud Geophys Geod 60:547-564

Wcisło M, Stabile TA, Telesca L, Eisner L (2017) Variations of attenuation and VP/VS ratio in the vicinity of wastewater injection: a case study of Costa Molina 2 well (High Agri Valley, Italy). Geophysics 83:B25-B31

Withers M, Aster R, Young C, Beiriger J, Harris M, Moore S, Trujillo J (1998) A comparison of select trigger algorithms for automated global seismic phase and event detection. Bull Seismol Soc Am 88:95-106 